\title{
KEMAMPUAN MENENTUKAN STRUKTUR DAN UNSUR KEBAHASAAN TEKS BERITA SISWA KELAS VIII SMP NEGERI 1 BARANGKA
}

\author{
Delisnawati $^{1}$, Yunus, ${ }^{2}$ dan La Ode Syukur. ${ }^{3}$ \\ pbsi.fkip.uho@gmail.com
}

1,2,3, Jurusan Pendidikan Bahasa dan Sastra Indonesia, Fakultas Keguruan dan Ilmu Pendidikan, Universitas Halu Oleo Kampus Hijau Bumi Tridharma Anduonohu, Kendari, Indonesia

\begin{abstract}
ABSTRAK
Tujuan dalam penelitian ini adalah mendeskripsikan kemampuan siswa dalam menentukan struktur dan unsur kebahasaan teks berita siswa kelas VIII SMP Negeri 1 Barangka. Jenis penelitian yang digunakan dalam penelitian ini tergolong dalam penelitian kelas karena peneliti turun langsung ke sekolah untuk mengumpulkan data sesuai dengan masalah penelitian. Metode yang digunakan dalam penelitian ini adalah metode deskriptif kuantitatif yaitu penelitian yang memberikan gambaran secara jelas mengenai kemampuan menentukan struktur dan unsur kebahasaan teks berita siswa kelas VIII SMP Negeri 1 Barangka yang selanjutnya dianalisis hasil data dengan menggunakan prinsip statistik yang berupa angka-angka. Responden dalam penelitian ini 95 yang terdiri dari empat kelas. Instrumen yang digunakan dalam penelitian ini adalah tes tertulis. Hasil penelitian menunjukkan bahwa secara individu terdapat $82(86,31 \%)$ siswa masuk kategori mampu dan $13(14 \%)$ siswa dikategorikan tidak mampu. Secara klasikal persentase kemampuan siswa dikategorikan mampu karena mencapai kriteria ketuntasan klasikal 85\%.
\end{abstract}

Kata Kunci: struktur; unsur kebahasaan; teks berita 


\begin{abstract}
The purpose of this study is to describe the ability of students to determine the structure and elements of language news texts for eighth grade students of SMP Negeri 1 Barangka. This type of research used in this study belongs to classroom research because researchers go directly to school for data collection in accordance with the research problem. The method used in this study is a quantitative descriptive method that is research that provides a clear picture of the ability to determine the structure and language elements of news texts for VIII grade students of SMP Negeri 1 Barangka, which are then analyzed by using statistical principles in the form of numbers. Respondents in this study 95 consisting of four classes. The instrument used in this study was a written test. The results showed that individually there were $82(86.31 \%)$ students included in the able category and $13(14 \%)$ students were categorized as unable. Classically the percentage of students' abilities is categorized as being able to achieve the $85 \%$ completeness criteria.
\end{abstract}

Keywords: structure; linguistics; news text

560 | Jurnal BASTRA (Bahasa dan Sastra), Vol. 4 No.4, Edisi Oktober 2019/e-ISSN: 25033875/http://ojs.uho.ac.id/index.php/BASTRA 


\section{PENDAHULUAN}

Indonesia di sekolah-sekolah bertujuan agar peserta didik mampu menguasai keterampilan berbahasa. Jika memperhatikan kurikulum 2013, muatan pembelajaran bahasa Indonesia dikelompokkan menjadi tujuan-tujuan pengajaran bahasa Indonesia yang berdasarkan tiga aspek, yaitu kebahasaan, keterampilan berbahasa, dan kesusastraan. Ketiga aspek tersebut penekanan pembelajaran bahasa Indonesia pada aspek keterampilan berbahasa. Pada pembelajaran bahasa Indonesia mencakup empat aspek keterampilan berbahasa yang meliputi menyimak, berbicara, membaca, dan menulis. Keempat aspek keterampilan tersebut harus dimiliki dan dikuasai oleh siswa dalam proses pembelajaran Bahasa Indonesia di sekolah.

Salah satu keterampilan berbahasa yang harus dikuasai oleh siswa adalah keterampilan membaca. Kemampuan membaca dapat memengaruhi keberhasilan siswa untuk mencari informasi dari berbagai media dan mampu memahami yang tersirat dalam bacaan serta menemukan informasi dan memahami pesan yang hendak disampaikan penulis.

Dalam kurikulum 2013 pembelajaran bahasa Indonesia diorientasikan pada pembelajaran berbasis teks. Perancangan pembelajaran bahasa Indonesia selain untuk memproduksi dan menggunakan teks sesuai fungsi dan tujuan sosialnya, juga memberi ruang kepada peserta didik untuk mengembangkan berbagai ilmu struktur berpikir, karena setiap teks memiliki struktur berpikir yang berbeda satu sama lain. Semakin banyak teks yang dikuasai, maka semakin banyak struktur berpikir yang dikuasai peserta didik. Oleh sebab itu, dalam pembelajaran bahasa Indonesia, teks dipandang sebagai satuan bahasa yang bermakna secara kontekstual.

Salah satu pembelajaran yang terdapat dalam buku siswa Bahasa Indonesia revisi tahun 2017 kurikulum 2013 pada tingkat Sekolah Menengah Pertama (SMP) adalah teks berita. Teks berita adalah salah satu materi yang tercantum dalam silabus mata pelajaran bahasa Indonesia kurikulum 2013 pada tingkatan Sekolah Menengah Pertama (SMP) khususnya pada kelas VIII yang Kompetensi Dasar terdapat pada 3.2 menelaah struktur dan kebahasaan teks berita (membanggakan dan memotivasi) yang didengar dan dibaca, dengan Indikator Pencapaian Kompetensi "Menemukan isi berdasarkan struktur dan unsur kebahasaan teks berita". Pada pembelajaran ini siswa dituntut untuk mampu menentukan struktur dan unsur kebahasaan teks berita yang diajarkan oleh guru.

Namun kenyataan masih ada sebagian siswa yang belum mampu menentukan struktur dan unsur kebahasaan teks berita, hal ini disebabkan beberapa faktor yaitu (1) siswa kurang memahami materi yang diajarkan sehingga berdampak pada rendahnya ketercapaian siswa dalam mencapai KKM yang sudah ditentukan oleh pihak disekolah, (2) siswa kurang termotivasi dalam belajar karena pembelajaran yang diberikan oleh guru. 
Olehnya guru harus pintar memilih strategi dan model pembelajaran mana yang sesuai dengan materi yang akan disampaikan agar siswa lebih memahami pelajaran.

Berdasarkan hasil observasi awal dengan guru mata pelajaran bahasa Indonesia SMP Negeri 1 Barangka dikatakan bahwa materi menentukan struktur dan kebahasaan berita merupakan salah satu materi yang diajarkan di sekolah kelas VIII pada semester satu dan telah diajarkan. Teks berita adalah salah satu materi yang tercantum dalam silabus mata pelajaran bahasa Indonesia kurikulum 2013 pada tingkatan Sekolah Menengah Pertama (SMP). Dalam proses pembelajaran, terlebih dahulu guru memberikan materi pembelajaran kepada siswa berupa materi dan contoh menentukan struktur dan unsur kebahasaan berita, kemudian dilanjutkan dengan latihan menentukan struktur dan unsur kebahasaan berita yang dilakukan oleh siswa bersama-sama dengan guru. Dengan hal tersebut peneliti tertarik melakukan penelitian pada salah satu materi pembelajaran yang ada pada mata pelajaran bahasa Indonesia tentang menentukan struktur dan kebahasaan teks berita untuk mengetahui kemampuan siswa dalam menentukan struktur dan unsur kebahasaan teks berita.

Berdasarkan latar belakang yang telah dikemukakan tersebut, maka yang menjadi rumusan masalah dalam penelitian ini adalah:
1. Bagaimanakah kemampuan menentukan struktur teks berita siswa kelas VIII SMP Negeri 1 Barangka?

2. Bagaimanakah kemampuan menentukan unsur kebahasaan teks berita siswa kelas VIII SMP Negeri 1 Barangka?

Penelitian ini bertujuan untuk mendeskripsikan kemampuan menentukan struktur dan unsur kebahasaan teks berita siswa kelas VIII SMP Negeri 1 Barangka.

Manfaat yang diharapkan dalam penelitian ini adalah sebagai berikut:

a. Sebagai bahan pertimbangan dan rujukan bagi sekolah selaku pembuat kebijakan terhadap program pembelajaran bahasa, khususnya menentukan struktur dan unsur kebahasaan teks berita.

b. Bagi guru, penelitian ini dapat dijadikan sebagai bahan informasi bagi perencanaan pelaksanaan dan pengevaluasian pembelajaran selanjutnya khususnya pembelajaran menentukan struktur dan unsur kebahasaan teks berita.

c. Bagi siswa, penelitian ini dapat dijadikan sebagai sumbangan pemikiran dalam meningkatkan pemahamannya tentang menentukan struktur dan unsur kebahasaan teks berita.

d. Bagi peneliti, sebagai bahan informasi tambahan bagi peneliti dan penelitipeneliti selanjutnya untuk dijadikan rujukan penelitian yang relevan.

Batasan operasional yang digunakan dalam penelitian ini adalah sebagai berikut: 
a. Kemampuan yang dimaksud dalam penelitian ini adalah kesanggupan yang dimiliki oleh siswa kelas VIII SMP Negeri 1 Barangka dalam menentukan struktur dan unsur kebahasaan teks berita.

b. Teks merupakan satuan lingual yang medianya dapat berupa lisan maupun tulisan yang mudah dipahami pembaca.

c. Berita adalah sebagai keterangan mengenai kejadian atau peristiwa yang hangat. Hangat berarti sesuatu yang baru saja terjadi dan penting untuk diketahui oleh khalayak.

d. Kebahasaan merupakan suatu unsur yang menjelaskan suatu kata/ penggunaan yang benar.

Struktur teks berita yang terdiri dari kepala berita, tubuh berita, dan ekor berita.

\section{METODE DAN TEKNIK PENELITIAN}

Jenis dan Metode Penelitian

Jenis Penelitian

Berdasarkan jenisnya penelitian ini merupakan penelitian kelas, karena peneliti turun ke sekolah tempat penelitian untuk mengumpulkan data sesuai dengan masalah dalam penelitian ini, yakni SMP Negeri 1 Barangka.

Metode Penelitian

Metode yang digunakan dalam penelitian ini adalah metode deskriptif kuantitatif. Deskriptif yaitu mendeskripsikan data penelitian secara objektif tentang kemampuan menentukan struktur dan unsur kebahasaan teks berita siswa kelas VIII SMP
Negeri 1 Barangka. Kuantitatif maksudnya adalah data yang terkumpul merupakan hasil pengukuran dan diolah dengan menggunakan rumus statistik.

Populasi dan Sampel Penelitian

Populasi Penelitian

Menurut Sugiyono (2015: 117), populasi adalah wilayah generalisasi yang terdiri atas: obyek/subjek yang mempunyai kualitas dan karakteristik tertentu yang ditetapkan oleh peneliti untuk dipelajari dan kemudian ditarik kesimpulannya. Populasi dalam penelitian ini adalah keseluruhan siswa kelas VIII SMP Negeri 1 Barangka tahun pelajaran 2018/2019yang berjumlah 125 orang yang terdiri dari lima kelas, dengan rincian kelas VIII ${ }^{1} 25$ siswa, VIII $^{2}$

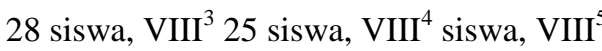
24 siswa.

Sampel Penelitian

Sugiyono (2015: 118) menyatakan bahwa sampel adalah bagian dari jumlah dan karakteristik yang dimiliki oleh populasi tersebut.

Teknik yang digunakan dalam pengambilan sampel pada penelitian ini adalah stratified proporsional random sampling yakni pengambilan sampel dengan cara merangking prestasi siswa dari yang terendah sampai yang tertinggi berdasarkan nilai ujian semester 2 (dua) kelas VII. Teknik ini digunakan bila populasi mempunyai anggota/unsur yang tidak homogen dan berstrata secara proporsional. Dengan demikian, sampel dalam penelitian ini mengambil 95 orang siswa dari jumlah 
populasi 125 siswa yang terdiri dari lima kelas.

Instrumen Penelitian

Dalam penelitian ini digunakan instrumen tertulis menentukan struktur dan unsur kebahasaan teks berita. Adapun yang akan ditentukan adalah struktur dan unsur kebahasaan teks berita.

Peneliti menyiapkan sebuah teks berita yang bersumber dari Buku Teks Pendamping Bahasa Indonesia untuk Siswa Kelas VIII Revisi 2016. Teks berita yang telah disiapkan adalah teks berita yang berasal dari buku dengan alasan struktur yang terkandung dalam teks berita tersebut masih asing bagi siswa karena jarang didengar.

Siswa membaca teks berita yang dibagikan untuk menjawab pertanyaan yang telah diberikan dalam lembar jawaban.

Teknik Pengumpulan Data

Data penelitian ini dikumpulkan dengan teknik pemberian tes yaitu menentukan struktur dan unsur kebahasaan teks berita. untuk mengarahkan responden dalam menelaah teks berita dengan baik, lama waktu pelajaran yang dibutuhkan untuk mengerjakan tes dalam menentukan struktur dan unsur kebahasaan teks berita adalah 2 jam pelajaran (2 X 40 menit) dengan pertimbangan bahwa dengan waktu yang telah disediakan siswa telah mampu mengerjakan tes menentukan struktur dan unsur kebahasaan teks berita sebagaimana yang telah menjadi instrumen penilaian. Selama pengumpulan data dalam penelitian di dalam kelas ditemani oleh guru mata pelajaran bahasa Indonesia, agar situasi selama pengumpulan data tetap kondusif sebagaimana seharusnya dalam mengikuti proses belajar mengajar.

Teknik Penilaian

Untuk menilai hasil tulisan siswa, teknik yang digunakan dalam menilai adalah teknik analitik, yaitu diarahkan pada ketepatan isi yang memuat struktur dan unsur kebahasaan teks berita.

Teknik Analisis Data

Data-data yang terkumpul dari hasil penelitian, selanjutnya diolah dan ditabulasi berdasarkan klasifikasi skor masing-masing siswa. Selanjutnya, data-data yang ditemukan diuraikan secara deskriptif dengan menggunakan teknik persentase sesuai dengan prinsip statistik. Hal tersebut bertujuan untuk menggambarkan hasil penelitian secara objektif, mempresentasikan tingkat kemampuan siswa pada aspek yang diujikan baik secara individual maupun klasifikasi.

Siswa dikatakan mampu secara individual jika mencapai Kriteria Ketuntasan Minimal (KKM) 70\% dari aspek yang dinilai. Sedangkan secara klasikal siswa dikatakan mampu apabila memiliki ketuntasan belajar $85 \%$ dari setiap aspek yang dinilai. Hal ini sesuai dengan standar ketuntasan yang digunakan di SMP Negeri 1 Barangka.

Rumus yang digunakan untuk menentukan persentase kemampuan siswa secara individual adalah:

$\mathrm{KI}=\frac{\text { Jumlah skor } \text { yang diperoleh }}{\text { Jumlah skor maksimal }} \times 100 \%$ 
Sedangkan rumus yang digunakan untuk menentukan ketuntasan belajar klasikal adalah :
Tabel 3

Rentang Kemampuan Siswa Pada Aspek

$\mathrm{KK}=$

Jumlah siswa yang secara individual memperoleh presentase $\geq 70$ $100 \%$

Jumlah sampel

Struktur dan Unsur Kebahasaan Teks

(Sumber. SMP Negeri 1 Barangka)

Ket : $\quad \mathrm{KI}=$ Kemampuan Individual

KK = Kemampuan Klasikal

Untuk lebih jelas dapat dilihat kriteria kategori kemampuan pada tabel berikut:

Tabel 1

\section{Rentang Kemampuan Siswa Pada Aspek}

Struktur Teks Berita

\begin{tabular}{ccc}
\hline $\begin{array}{c}\text { Kategori } \\
\text { Kemampuan }\end{array}$ & $\begin{array}{c}\text { Rentang } \\
\text { Skor }\end{array}$ & $\begin{array}{c}\text { Persentase } \\
\text { Kemampuan }\end{array}$ \\
\hline Mampu & $9-12$ & $75 \%-100 \%$ \\
\hline Tidak Mampu & $1-8$ & $8 \%-66,6 \%$ \\
\hline
\end{tabular}

Tabel 2

Rentang Kemampuan Siswa Pada Aspek

Unsur Kebahasaan Teks Berita

\begin{tabular}{ccc}
\hline $\begin{array}{c}\text { Kategori } \\
\text { Kemampuan }\end{array}$ & $\begin{array}{c}\text { Rentang } \\
\text { Skor }\end{array}$ & $\begin{array}{c}\text { Persentase } \\
\text { Kemampuan }\end{array}$ \\
\hline Mampu & $11-15$ & $73,33 \% \%-$ \\
& & $100 \%$ \\
\hline Tidak Mampu & $1-10$ & $6,6 \%-$
\end{tabular}

Berita

\begin{tabular}{ccc}
\hline $\begin{array}{c}\text { Kategori } \\
\text { Kemampuan }\end{array}$ & $\begin{array}{c}\text { Rentang } \\
\text { Skor }\end{array}$ & $\begin{array}{c}\text { Persentase } \\
\text { Kemampuan }\end{array}$ \\
\hline Mampu & $19-27$ & $70 \%-100 \%$ \\
\hline Tidak & $1-18$ & $3,7 \%-66,66 \%$ \\
Mampu & & \\
& &
\end{tabular}

Berdasarkan pedoman penilaian, dapat diketahui hasil tes menentukan struktur dan unsur kebahasaan teks berita. Siswa dikategorikan mampu apabila siswa mendapat skor 19 sampai 27 dengan nilai 70 sampai 100 dan persentase kemampuan $70 \%$ sampai $100 \%$. Siswa dikategorikan tidak mampu apabila siswa mendapat skor 1 sampai 18 dengan nilai 3,7 sampai 66,66 dan persentase kemampuan $3,3 \%$ sampai $66,66 \%$.

\section{HASIL PENELITIAN DAN}

PEMBAHASAN

2.1.Deskripsi

Kemampuan

Menentukan Struktur Teks Berita Siswa Kelas VIII SMP Negeri 1

\section{Barangka}

Berdasarkan hasil tes menentukan struktur teks berita siswa kelas VIII 
SMP Negeri 1 Barangka, pemerolehan siswa dapat dilihat pada tabel berikut ini.

Tabel 4

Persentase Kemampuan Menentukan Struktur Teks Berita

\begin{tabular}{cccc}
\hline No. & Kategori & Frekuensi & Persentase \\
\hline 1 & Mampu & 75 & $78,95 \%$ \\
\hline 2 & Tidak & 20 & $21,05 \%$ \\
& Mampu & & \\
& & & $100 \%$ \\
\hline & Jumlah & 95 & \\
\hline
\end{tabular}

Berdasarkan tabel tersebut, maka dapat disimpulkan bahwa terdapat 75 siswa

$(78,95 \%)$ yang secara individual

dikategorikan mampu dan terdapat 20 siswa $(21,05 \%)$ dikategorikan tidak mampu pada aspek menentukan struktur teks berita.

Selanjutnya untuk mengukur kemampuan menentukan struktur teks berita secara klasikal digunakan rumus sebagai berikut.

$\mathrm{KK}=$

Jumlah siswa yang secara individual memperoleh presentase $\geq 70$ Jumlah sampel

X $100 \%$

(Sumber. SMP Negeri 1 Barangka)

Keterangan : Kemampuan Klasikal

$\mathrm{KK}=$

$\underline{\text { Jumlah siswa yang secara individual memperoleh presentase } \geq 70}$ Jumlah sampel

X $100 \%$

$$
\begin{aligned}
& \mathrm{KK}=\frac{75}{95} X 100 \% \\
& \mathrm{KK}=78,95 \%
\end{aligned}
$$

Dengan demikian, bila dilihat dari

kemampuan menentukan struktur teks berita secara klasikal masuk kategori tidak mampu, karena kemampuan siswa 78,95\% atau

kurang dari batas kemampuan klasikal $85 \%$.

2.2 Deskripsi Kemampuan Menentukan

Unsur Kebahasaan Teks Berita Siswa

Kelas VIII SMP Negeri 1 Barangka

Tabel 5

Persentase Kemampuan Menentukan

Unsur Kebahasaan Teks Berita

\begin{tabular}{lccc}
\hline No. & Kategori & Frekuensi & Persentase \\
\hline 1 & Mampu & 71 & $74,73 \%$ \\
& & & \\
\hline 2 & Tidak & 24 & $25,26 \%$ \\
& Mampu & &
\end{tabular}

\begin{tabular}{lll}
\hline Jumlah & 95 & $100 \%$
\end{tabular}

Berdasarkan tabel rentang kemampuan siswa, maka dapat disimpulkan bahwa terdapat 71 siswa $(74,73 \%)$ yang secara individual dikategorikan mampu dan terdapat 24 siswa $(25,26 \%)$ dikategorikan tidak mampu pada aspek menentukan unsur kebahasaan teks berita.

Selanjutnya untuk mengukur kemampuan menentukan unsur kebahasaan teks berita secara klasikal digunakan rumus sebagai berikut.

$\mathrm{KK}=$

Jumlah siswa yang secara individual memperoleh presentase $\geq 70$ X $100 \%$ Jumlah sampel

(Sumber. SMP Negeri 1 Barangka)

Keterangan :

KK : Ketuntasan Klasikal

$\mathrm{KK}=$

$\frac{\text { Jumlah siswa yang secara individual memperoleh presentase } \geq 70}{\text { Jumlah sampel }} X 100 \%$

$\mathrm{KK}=\frac{71}{95} X 100 \%$

$\mathrm{KK}=74,73 \%$ 
Dengan demikian, bila dilihat dari kemampuan menentukan unsur kebahasaan teks berita secara klasikal masuk kategori tidak mampu, karena kemampuan siswa mencapai $74,73 \%$ atau kurang dari batas kemampuan klasikal $85 \%$.

2.3 Deskripsi Kemampuan Siswa dalam Aspek Struktur dan Unsur Kebahasaan Teks Berita Siswa Kelas VIII SMP Negeri 1 Barangka

Tabel 6

Persentase Kemampuan

Menentukan Struktur dan Unsur

Kebahasaan Teks berita

\begin{tabular}{cccc}
\hline No. & Kategori & Frekuensi & Persentase \\
\hline 1 & Mampu & 82 & $86,31 \%$ \\
& & & \\
\hline 2 & Tidak & 13 & $14 \%$ \\
& Mampu & & \\
& & & $100 \%$
\end{tabular}

Berdasarkan tabel di atas, maka dapat disimpulkan bahwa terdapat 82 siswa $(86,31 \%)$ yang secara individual dikategorikan mampu dan terdapat 13 siswa (14\%) dikategorikan tidak mampu pada aspek menentukan struktur dan unsur kebahasaan teks berita.

Selanjutnya, untuk mengukur kemampuan menentukan struktur dan unsur kebahasaan teks berita secara klasikal digunakan rumus berikut.

$\mathrm{KK}=$ $\frac{\text { Jumlah siswa yang secara individual memperoleh presentase } \geq 70}{\text { Jumlah sampel }} X 100 \%$

(Sumber. SMP Negeri 1 Barangka)

$$
\begin{aligned}
& \mathrm{KK}=\frac{82}{95} X 100 \% \\
& \mathrm{KK}=86,31 \%
\end{aligned}
$$

Dengan demikian, bila dilihat dari kemampuan menentukan struktur dan unsur kebahasaan teks berita secara klasikal masuk kategori mampu, karena kemampuan siswa mencapai $86,31 \%$ atau lebih dari batas kemampuan secara klasikal $85 \%$.

\subsection{Interpretasi Hasil Penelitian}

Dari hasil analisis data kemampuan menentukan struktur dan unsur kebahasaan teks berita siswa kelas VIII SMP Negeri 1 Barangka dapat dilihat bahwa siswa memiliki kemampuan yang berbeda-beda untuk lebih jelasnya dapat dilihat pada tabel berikut.

Tabel 7

Rangkuman Data Kemampuan

Menentukan Struktur dan Unsur Kebahasaan Teks Berita Siswa Kelas VIII SMP Negeri 1 Barangka

\begin{tabular}{llll}
\hline No. & Aspek & Persentase & Kategori \\
& Penilaian & kemampuan &
\end{tabular}

(\%)

\begin{tabular}{cccc}
\hline 1 & $\begin{array}{c}\text { Struktur } \\
\text { Teks Berita }\end{array}$ & $78,95 \%$ & $\begin{array}{c}\text { Tidak } \\
\text { Mampu }\end{array}$ \\
\hline 2 & Unsur & $74,73 \%$ & Tidak \\
& Kebahasaan & & Mampu \\
& Teks Berita & & \\
& & & \\
\hline 3 & Struktur & $86,31 \%$ & Mampu \\
& dan Unsur & & \\
& Kebahasaan & & \\
& Teks Berita & \\
&
\end{tabular}


Berdasarkan perolehan data pada tabel di atas, maka dapat diinterpretasikan bahwa pada aspek struktur teks berita persentase kemampuan yang dicapai secara klasikal adalah 78,95\%. Angka ini masih berada di bawah standar ketuntasan klasikal yang telah ditetapkan sebelumnya, yakni $85 \%$. Hasil penilaian menunjukkan struktur teks berita meliputi kepala berita, tubuh berita, ekor berita. Kepala berita menduduki nilai tertinggi dengan persentase $98,68 \%$, diikuti ekor berita dengan persentase $95,78 \%$ dan tubuh berita menduduki nilai terendah dengan persentase $72,80 \%$. Kemudian aspek unsur kebahasaan teks berita persentase kemampuan yang dicapai secara klasikal adalah 74,73\%. Angka ini masih di bawah standar ketuntasan klasikal yang telah ditetapkan sebelumnya, yakni $85 \%$. Hasil penilaian menunjukkan unsur kebahasaan teks berita meliputi penggunaan kalimat langsung, penggunaan konjungsi bahwa, penggunaan kata kerja mental, penggunaan keterangan waktu \& tempat, penggunaan konjungsi bahwa. Penggunaan konjungsi bahwa menduduki nilai tertinggi dengan persentase $90,52 \%$, diikuti penggunaan kata kerja mental dengan persentase 90\%, penggunaan kalimat langsung dengan persentase $89,82 \%$, penggunaan konjungsi temporal dengan persentase $70,26 \%$, penggunaan keterangan waktu dan tempat menduduki nilai terendah dengan persentase 66,05\%. Pada aspek struktur dan unsur kebahasaan teks berita persentase kemampuan yang dicapai secara klasikal yaitu $86,31 \%$. Angka ini telah memenuhi standar ketuntasan klasikal yang telah ditetapkan sebelumnya yakni $85 \%$. Hasil penelitian menunjukkan struktur dan unsur kebahasaan teks berita, aspek struktur teks berita menduduki nilai tertinggi dengan persentase $85,26 \%$ kemudian unsur kebahasaan teks berita dengan persentase $78,38 \%$. Berdasarkan aspek yang dinilai persentase yang dicapai dalam menentukan struktur dan unsur kebahasaan teks berita adalah $81,44 \%$.

Berdasarkan hasil tersebut dan analisis data secara klasikal dengan rumus statistik yang telah ditentukan, maka secara klasikal kemampuan menentukan struktur dan unsur kebahasaan siswa kelas VIII SMP Negeri 1 Barangka masuk dalam kategori mampu karena kemampuan siswa mencapai $86,31 \%$ dan telah memenuhi standar ketuntasan klasikal, yakni 85\%. Kemampuan siswa dalam menentukan struktur teks berita secara klasikal tidak mampu karena secara individu terdapat 75 siswa yang memperoleh persentase $\geq 70$ dengan persentase kemampuan $78,95 \%$. Kemampuan siswa dalam menentukan unsur kebahasaan teks berita secara klasikal tidak mampu karena secara individu terdapat 71 siswa yang memperoleh persentase $\geq 70$ dengan persentase kemampuan $74,73 \%$. Kemampuan menentukan struktur dan unsur kebahasaan teks berita secara klasikal masuk kategori mampu karena secara individu terdapat $82 \quad(86,31 \%)$ siswa yang memperoleh persentase $\geq 70$, dengan rincian terdapat 54 siswa mampu menentukan struktur dan unsur kebahasaan teks berita, 
15 siswa yang tidak mampu menentukan struktur teks berita setelah digabungkan dengan skor perolehan menentukan unsur kebahasaan teks berita siswa menjadi mampu, 13 siswa yang tidak mampu menentukan unsur kebahasaan teks berita setelah digabungkan dengan skor perolehan menentukan struktur teks berita siswa menjadi mampu.

\section{PENUTUP}

\section{Kesimpulan}

Berdasarkan hasil penelitian dan analisis data mengenai menentukan struktur dan unsur kebahasaan teks berita, dapat disimpulkan bahwa kemampuan menentukan struktur teks berita secara klasikal tidak mampu karena kemampuan siswa secara klasikal hanya mencapai $78,95 \%$ atau kurang dari ketuntasan klasikal $85 \%$. Berdasarkan hasil penelitian dan analisis data mengenai menentukan unsur kebahasaan teks berita, dapat disimpulkan bahwa kemampuan menentukan unsur kebahasaan teks berita secara klasikal tidak mampu karena kemampuan siswa secara klasikal hanya mencapai $74,73 \%$ atau kurang dari ketuntasan klasikal 85\%.

Dilihat dari hasil penelitian dan analisis data, dapat disimpulkan bahwa kemampuan menentukan struktur dan unsur kebahasaan teks berita siswa kelas VIII SMP Negeri 1 Barangka secara individu terdapat 82 orang yang dikategorikan mampu sedangkan 13 orang siswa dikategorikan tidak mampu. Jumlah kemampuan siswa dari rincian, 11 orang mendapat skor 26 dengan persentase
$96,29 \%$, 16 orang mendapat skor 25 dengan persentase $92,59 \%, 8$ orang mendapat skor 24 dengan persentase $88,88 \% \%, 12$ orang mendapat skor 23 dengan persentase $85,18 \%, 10$ orang mendapat skor 22 dengan persentase $81,48 \%, 9$ orang mendapat skor 21 dengan persentase $77,77 \% \%, 7$ orang mendapat skor 20 dengan persentase $74 \%, 9$ orang mendapat skor 19 dengan persentase $70 \%, 4$ orang mendapat skor 18 dengan persentase $66,66 \% \%, 6$ orang mendapat skor 17 dengan persentase $62,96 \%, 2$ orang mendapat skor 14 dengan persentase $51,85 \%$, 1 orang mendapat skor 13 dengan persentase $48,14 \%$. Dari hasil perhitungan secara klasikal yang mencapai $86,31 \%$ maka dengan ini dapat dikatakan siswa mampu karena mencapai ketuntasan minimal secara individu yaitu $70 \%$ dan secara klasikal siswa dikategorikan mampu karena mencapai ketuntasan klasikal yaitu $85 \%$.

Dengan melihat kemampuan siswa menentukan struktur dan unsur kebahasaan teks berita, maka peneliti menyarankan sebagai berikut.

1. Guru mata pelajaran perlu memperhatikan secara khusus kepada siswa yang tidak mampu secara individu maupun secara klasikal dengan banyak memberikan pemahaman tentang materi teks berita.

2. Untuk pembelajaran teks berita, guru dapat menyesuaikan ketuntasan materi pembelajaran dengan pemahaman siswa sehingga 
keseluruhan aspek penilaian dapat dipahami oleh siswa.

3. Dalam proses pembelajaran lebih ditingkatkan lagi dengan sering memberikan latihan menentukan struktur dan unsur kebahasaan teks berita.

\section{DAFTAR PUSTAKA}

Ahmad, H.P dan Alek. 2016. Bahasa Indonesia untuk Perguruan Tinggi. Jakarta: Erlangga.

Atmadja, Nengah Bawa dan Luh Putu Sri Ariyani. 2018. Sosiologi Media. Depok: Rajawali Pers.

Baksin, Askurifai. 2016. Jurnalistik Televisi Teori dan Praktik. Bandung: Simbiosa Rakatama Media.

Dalman. 2014. Keterampilan Membaca. Jakarta: PT. Rajagrafindo Persada.

Ishwara, Luwi. 2016. Jurnalisme Dasar. Jakarta: Kompas.

Junaedi, Fajar. 2015. Jurnalisme Penyiaran dan Reportase Televisi. Jakarta: Prenada Media Group.

Kosasih, E. 2017. Buku Guru Bahasa Indonesia. Jakarta: Kementerian Pendidikan dan Kebudayaan.
Kosasih, E. 2017. Buku Siswa Bahasa Indonesia. Jakarta: Kementerian Pendidikan dan Kebudayaan.

Kosasih, E. 2019. Jenis-Jenis Teks. Bandung: Yrama Widya.

Mondry. 2016. Pemahaman Teori dan Praktik Jurnalistik. Bogor: Khalia Indonesia.

Mu'takif, A. 2011. Wartawan Handal Diburu Media Masa. Surabaya: CV. Garuda Mas Sejahtera.

Musman, Asti dan Nadin Mulyadi. 2017. Jurnalisme Dasar. Bangunharjo: Komunika.

Nurhadi. 2016. Teknik Membaca. Jakarta: PT Bumi Aksara.

Saddhono, Kundharu dan St. Y. Slamet. 2014. Pembelajaran Keterampilan Berbahasa Indonesia. Yogyakarta: Graha Ilmu.

Sudarman, Paryati. 2008. Menulis di Media Masa. Yogyakarta: Pustaka Pelajar.

Sugiyono. 2015. Metode Penelitian Pendidikan (Pendekatan Kuantitatif, Kualitatif, dan R\&D). Bandung. Alfabeta.

Sumadiria, AS Haris. 2017. Jurnalistik Indonesia Menulis Berita dan Feature. Bandung: Simbiosa Rekatama Media.

Tarigan, Henry Guntur. 2008. Membaca Sebagai Suatu Keterampilan Berbahasa. Bandung: Angkasa. 